\title{
Stem-cell paper corrected
}

The authors of a controversial paper on stem cells publish a correction of their work in this week's issue of Nature (see page 880 ), but say their overall conclusions still stand.

The paper in question, published in

2002, claimed to find evidence for so-called 'multipotent adult progenitor cells', or MAPCs, in mouse bone marrow ( $Y$. Jiang et al. Nature 418, 41-49; 2002). The work was led by

Catherine Verfaillie, now director of the Stem Cell Institute at the Catholic University of Leuven, in Belgium.

The correction states that figures showing proteins on the surface of the MAPCs contained many errors, including duplications. Verfaillie's group provides replacement data and says that the correction does not undermine the paper's conclusion that MAPCs can give rise to a wide range of different cell types.

The paper challenged the prevailing idea that only stem cells derived from embryos were highly flexible. Some of its results have been reproduced by other labs, but no one has been able to replicate the work independently in its entirety.

"I believe that despite the hype over the mistake, we and Nature made the conclusion that the final findings of the paper still stand," says Verfaillie.

This February, an investigation convened by the University of Minnesota - Verfaillie's former institution - found that her group had used incorrect procedures in the Nature paper, and that some of the data contained in it might be flawed. The investigation was a response to questions from a reporter from the magazine New Scientist, who pointed out that the figure corrected today was partly reproduced with different labels in another paper in the journal Experimental Hematology (Y. Jiang et al. Exp. Hematol. 30, 896-904; 2002).

In response to the investigation, Nature convened a peer-review panel to analyse the data from the 2002 paper. According to Nature, the experts concluded that although the figure data were flawed, the paper's conclusions are still valid.

No allegations of fraud or misconduct have been levelled at Verfaillie or anyone from her group. There are still two investigations ongoing - one at the University of Minnesota and one at the Catholic University of Leuven - into a second set of allegations raised by New Scientist. These concern data from a paper in the journal Blood (M. Reyes et al. Blood 98, 2615-2625; 2001) and data in a US patent filing.

Verfaillie says her group cannot explain how the errors in the Nature paper occurred: "Why this happened, we have not been able to determine," she says.

Erika Check

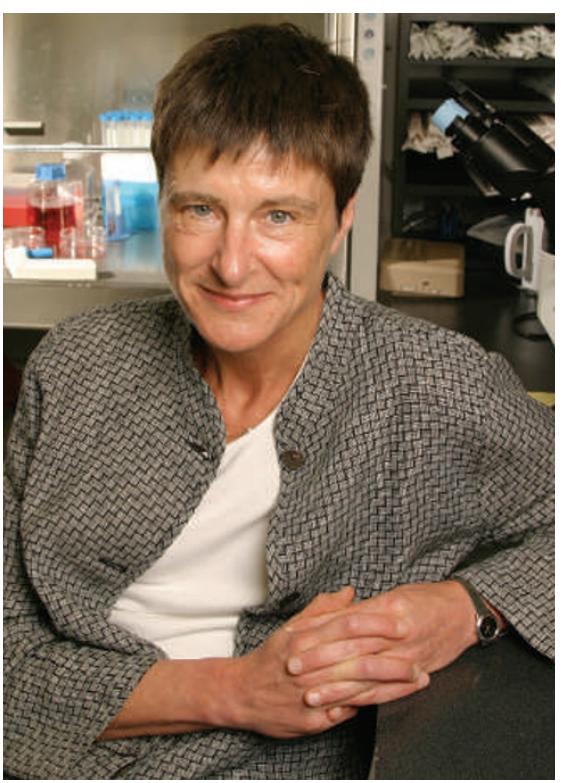

Catherine Verfaillie defends her team's work. funding agencies, now must winnow out those projects to be built from those to be abandoned. This October, they will announce which projects on the list will receive initial funding for technical design studies; an updated roadmap is to be produced by autumn 2008. Projects that are chosen for funding will require one country to take the lead, as Germany has done for the XFEL and the icebreaker.
But even that can be tricky, as negotiating the details of multinational EU projects is a notoriously cumbersome process. Building the XFEL, for example, required separate bilateral agreements between Germany and all the 12 other participating countries. And although Germany had said early on that it would cover $60 \%$ of the building costs and $75 \%$ of the operational costs, it took almost four years to finalize agreements with all partners. The money must come from some extra pot, as the EU's seventh Framework programme for research, which runs from 2007 to 2013, has only an embryonic budget for infrastructures - just enough to fund design studies and facilitate access to existing machines.

Peter Tindemans, who chairs the ESS initiative, suggests that a fraction of the EU's overall budget surplus, some
$€ 3$ billion to $€ 4$ billion each year, should be put aside for funding research facilities. That's twice the current EU spending on infrastructures, and roughly equal to US spending.

"The ministers say research infrastructures are an area where Europe needs to act as a union," says Tindemans. "Let's remind them of their promise to put their money where their mouth is."

Quirin Schiermeier 